\title{
"PENGARUH REPUTASI PERUSAHAAN RENTAL DAN RELATIONSHIP VALUE TERHADAP KEPERCAYAAN DAN KOMITMEN SERTA LOYALITAS PERUSAHAAN PENGGUNA JASA PERSEWAAN KENDARAAN DI PROVINSI KALIMANTAN TIMUR"
}

\author{
“The Effect of Lessor Company's Reputation and Relationship \\ Value on Trust and Commitment and Loyalty of Company \\ which Use Rental Car in East Kalimantan Province"
}

\author{
Novel Reonald \\ (Fakultas Ekonomi, Universitas Widya Gama Mahakam) \\ J1. KH. Wahid Hasyim, Sempaja, Samarinda, Kalimantan Timur, Indonesia \\ Telp : (0541) 734294-737222, Fax : (0541) 736572 \\ Email : novelreonald@uwgm.ac.id
}

\begin{abstract}
Abstrak
Tujuan dari penelitian ini adalah untuk menguji pengaruh perusahaan kendaraan sewa (lessor) reputasi dan nilai hubungan pada loyalitas dari perusahaan kendaraan pengguna (penyewa) melalui kepercayaan dan komitmen dari lessee dalam industri penyewaan mobil. Kerangka konseptual penelitian terdiri dari konstruksi berikut: reputasi, nilai hubungan, kepercayaan, komitmen, dan loyalitas. Selain itu, 9 hipotesis dikembangkan dan diuji. Faktor memuat dan membangun kehandalan yang digunakan untuk menguji validitas dan reliabilitas instrumen. Sebanyak 172 kuesioner kembali sepenuhnya dari perusahaan yang menggunakan mobil sewa di Kalimantan Timur melalui e-mail maka mereka diproses dengan menggunakan teknik analisis SEM untuk pengujian hipotesis. dukungan yang kuat ditemukan untuk 8 dari 9 hipotesis. Temuan menunjukkan bahwa 1. Reputasi memiliki pengaruh yang signifikan pada kepercayaan, 2. Reputasi memiliki pengaruh yang signifikan terhadap komitmen, 3. Reputasi tidak memiliki pengaruh yang signifikan terhadap loyalitas, 4. Nilai Hubungan memiliki pengaruh yang signifikan terhadap loyalitas, 5. nilai Hubungan memiliki pengaruh yang signifikan terhadap kepercayaan, 6. nilai Hubungan memiliki pengaruh yang signifikan terhadap komitmen, 7. Kepercayaan memiliki pengaruh yang signifikan terhadap komitmen, 8. Kepercayaan memiliki pengaruh yang signifikan terhadap loyalitas, 9. komitmen memiliki pengaruh yang signifikan terhadap loyalitas. Penelitian ini bekerja dalam domain pemasaran layanan hubungan B2B. Studi ini menunjukkan bahwa reputasi penyedia yang baik tidak selalu memiliki pengaruh pada loyalitas pelanggan. Oleh karena itu, penyedia harus meningkatkan nilai hubungan, kepercayaan dan komitmen yang telah terbukti loyalitas pengaruh pelanggan, baik secara langsung maupun tidak langsung.

Kata kunci: B2B hubungan layanan pemasaran, reputasi, nilai hubungan, kepercayaan, komitmen, loyalitas.
\end{abstract}

\begin{abstract}
The purpose of this study is to examine the influence of vehicle leasing company (lessor) reputation and relationship value on loyalty of vehicle user company (lessee) through trust and commitment of lessee in car rental industry. The conceptual framework of the study consists of the following constructs: reputation, relationship value, trust, commitment, and loyalty. Moreover, 9 hypotheses were developed and tested. Loading factor and construct reliability were used to test the validity and reliability of the instrument. A total of 172 questionnaires were returned completely from companies using leased cars in East Kalimantan by e-mail then they processed using SEM analysis techniques for hypotheses testing. Strong support was found for 8 of the 9 hypotheses. Findings reveal that 1. Reputation had significant influence on trust, 2. Reputation had significant influence on commitment, 3. Reputation had no significant influence on loyalty, 4. Relationship value had significant influence on loyalty, 5. Relationship value had significant influence on trust, 6. Relationship value had significant influence on commitment, 7. Trust had significant influence on commitment, 8. Trust had significant influence on
\end{abstract}


loyalty, 9. Commitment had significant influence on loyalty. This study worked within the domain of $B 2 B$ relationship service marketing. This study showed that the reputation of a good provider did not always have an influence on customer loyalty. Therefore, providers need to increase relationship value, trust and commitment that have been proven influence customer loyalty, either directly or indirectly.

Keywords: B2B relationship service marketing, reputation, relationship value, trust, commitment, loyalty

\section{PENDAHULUAN}

\section{Latar Belakang}

Perusahaan rental tentu saja berharap bahwa perusahaan penyewa akan terus menyewa kendaraan darinya atau loyal untuk jangka yang panjang. Kotler and Keller (2006: 17-18) dan Ravald and Grönroos (1996) mengatakan bahwa pemasaran relasional (relationship marketing) bertujuan membentuk hubungan jangka panjang yang saling menguntungkan antara pihak-pihak terkait atau dari sisi provider membuat pelanggan loyal dan berhubungan dengan stabil.

Loyalitas pelanggan sangat penting karena setiap pelanggan dapat memberikan kontribusi yang besar terhadap pendapatan provider. Hal tersebut dapat terjadi sebab provider pada $B 2 B$ marketing (business-to-business marketing atau pemasaran korporat) umumnya tidak memiliki banyak pelanggan, sehingga kehilangan satu pelanggan berarti kehilangan kesempatan mendapatkan pemasukan yang besar yang biasa didapatkan perusahaan. Hal tersebut sebagaimana dikatakan oleh Pick (2010) bahwa provider pada B2B marketing sangat menderita saat kehilangan pelanggannya, sementara mendapatkan kembali pelanggan tersebut sama sulitnya dengan mendapatkan pelanggan baru. Hal ini ditunjang pula dengan jumlah pelanggan pada pasar bisnis yang relatif kecil. Demikian pula pada bisnis persewaan kendaraan. Oleh sebab itu, loyalitas perusahaan penyewa terhadap perusahaan rental mutlak ada. Maka dari itu, studi ini secara umum bertujuan untuk mengetahui pengaruh beberapa variabel terhadap loyalitas perusahaan penyewa pada perusahaan rental.

Loyalitas perusahaan penyewa berhubungan dengan komitmennya terhadap perusahaan rental. Tian et al. (2008) mengatakan bahwa komitmen pelanggan yang tinggi membuat loyalitas pelanggan kepada provider-nya juga tinggi. Komitmen adalah keadaan psikologis terhadap keterikatan hubungan, sementara loyalitas menunjukkan perilaku dari keterikatan hubungan tersebut. Komitmen pelanggan dilandasi manfaat dari hubungan yang dijalinnya dengan providernya. Adanya keinginan yang tinggi untuk mendapatkan manfaat secara kontinu membuat pelanggan terus melakukan pembelian ulang dan membeli lebih banyak kepada provider. Hal ini menunjukkan loyalitasnya kepada provider tersebut.

Loyalitas perusahaan penyewa kepada perusahaan rental juga dapat dipengaruhi oleh kepercayaannya. Rauyruen and Miller (2007) mengatakan bahwa dalam hubungan bisnis, provider harus mendapatkan kepercayaan dari pelanggan terlebih dahulu bila menginginkan pelanggan tersebut menjadi loyal kepadanya. Kepercayaan pelanggan bahwa provider memiliki kemampuan yang tinggi membuat pelanggan menjadi loyal kepadanya. Pelanggan yang merasa bahwa provider memprioritas kepentingan pelanggannya yang disertai kredibilitas yang tinggi dari provider membuat pelanggan akan merekomendasikan provider kepada mitranya agar mitra tersebut juga dapat merasakan hal positif yang sama sebagaimana yang dirasakannya. Rasa percaya yang tinggi terhadap prioritas kepentingan provider dan rasa percaya terhadap kredibilitas provider yang tinggi menunjukkan kepercayaan pelanggan. Kepercayaan tersebut mempengaruhi loyalitasnya yang ditunjukkan melalui rekomendasi untuk menggunakan provider yang digunakannya kepada pihak lain.

Kepercayaan juga dapat mempengaruhi komitmen melalui mekanisme kontrol. Masingmasing perusahaan mempunyai regulasi atau mekanisme kontrol yang dituangkan pada suatu prosedur standar agar mereka terhindar dari suatu keadaan yang tidak menguntungkan. Saat melakukan transaksi bisnis, mekanisme kontrol yang disepakati bersama oleh perusahaanperusahaan yang berhubungan umumnya dituangkan dalam perjanjian. Mekanisme 
kontrol hubungan tersebut tentu menimbulkan biaya yang tidak sedikit. Pada pihak-pihak yang memiliki kepercayaan satu sama lain, biaya ini dapat dikurangi berdasarkan keyakinan bahwa tidak terdapat pihak yang akan mencurangi perjanjian yang telah disepakati. Penurunan biaya tersebut membuat komitmen antar pihakpihak yang berhubungan meningkat. Hal itu karena komitmen ialah keadaan hubungan dua pihak yang dekat karena adanya motif ekonomi, yakni mendapatkan keuntungan ataupun mengurangi biaya (Walter et al., 2002).

Pada studi ini, relationship value bagi perusahaan penyewa juga dapat mempengaruhi kepercayaannya terhadap perusahaan rental. Relationship value yang tinggi membuat kepercayaan pelanggan terhadap provider juga tinggi. Keuntungan yang lebih besar dibandingkan korbanan yang dikeluarkan untuk provider tersebut membuat kepercayaan pelanggan terhadap provider-nya meningkat. Hal ini karena pelanggan merasa bahwa provider memprioritaskan kepentingan pelanggannya dibandingkan kepentingan provider itu sendiri. Kemampuan provider untuk memberikan manfaat yang besar itu juga membuat pelanggan menilai bahwa provider memiliki kompetensi yang tinggi terhadap pekerjaannya (Gil-Saura et al., 2009; Ulaga and Eggert 2006).

Relationship value juga dapat mempengaruhi loyalitas perusahaan penyewa. Čater and Čater (2009) mengatakan bahwa loyalitas pada suatu hubungan relasional korporat merupakan sesuatu yang dilandasi rasionalitas, maka harga dan kualitas produk (sebagai bagian dari relationship value) merupakan hal yang harus diperhatikan oleh provider. Ketika harga dan kualitas produk yang ditawarkan sepanjang hubungan dianggap

\section{METODE PENELITIAN}

\section{Rancangan Penelitian \\ Populasi, Sampel dan Teknik Pengambilan Sampel \\ Populasi pada studi ini ialah perusahaan yang menggunakan jasa persewaan kendaraan di Kalimantan Timur. Sementara respondennya merupakan satu orang penentu keputusan mengenai pemakaian jasa persewaan kendaraan di perusahaannya (perusahaan penyewa). Data populasi perusahaan penyewa yang digunakan}

sesuai oleh pelanggan, maka pelanggan mengatakan bahwa nilai hubungan (relationship value) dengan provider-nya tinggi, sehingga loyalitasnya terhadap provider tersebut juga tinggi yang ditunjukkan dengan dilakukannya pembelian ulang dan pemberian rekomendasi kepada pihak lain mengenai provider-nya.

Reputasi perusahaan rental tidak hanya dianalisa pada bagian awal atau sebelum adanya hubungan dengan perusahaan penyewa. Bennet and Gabriel (2001) mengatakan bahwa pelanggan tentu lebih memilih untuk bekerja sama dengan perusahaan bereputasi tinggi, terutama untuk meminimalkan risiko pada suatu hubungan jangka panjang atau sistem kontrak dengan masa tertentu. Oleh sebab itu, reputasi perusahaan rental merupakan satu faktor pula yang dapat mempengaruhi loyalitas perusahaan penyewa yang sedang berhubungan dengannya. Miremadi et al. (2011) mengatakan bahwa ada banyaknya pesaing dalam suatu bisnis membuat provider dengan reputasi yang baik memiliki suatu competitive advantage dalam mempertahankan dan meningkatkan loyalitas pelanggannya. Reputasi provider yang tinggi membuat loyalitas pelanggan juga tinggi sebab pelanggan tidak akan beralih kepada provider lain bila mereka menilai provider lain tidak lebih baik dibandingkan provider yang bekerja sama dengannya saat ini.

Berdasarkan pada latar belakang yang telah dikemukakan di atas, penulis ingin meneliti tentang "Pengaruh Reputasi Perusahaan Rental dan Relationship Value terhadap Kepercayaan dan Komitmen serta Loyalitas Perusahaan Pengguna Jasa Persewaan Kendaraan di Provinsi Kalimantan Timur".

pada studi ini didapatkan dari data pelanggan perusahaan rental di Kalimantan Timur.

Berdasarkan data yang diperoleh dari ASPANJI (2011), jumlah perusahaan di Kalimantan Timur dengan spesifikasi usaha penyewaan alat angkutan darat, laut dan udara pada tahun 2011 berjumlah 439 perusahaan. Kemudian, dikirimkan kepada perusahaanperusahaan tersebut permohonan melalui surat agar mereka bersedia memberikan data pelanggannya dengan kriteria bahwa pelanggan tersebut: 1. menyewa jenis kendaraan pengangkut orang dengan tipe light vehicle 
(kendaraan kecil); 2. menyewa minimal satu unit kendaraan; 3. merupakan perusahaan yang beroperasi di Provinsi Kalimantan Timur dengan bidang usaha salah satu dari pertambangan batu bara atau migas (minyak dan gas bumi) atau perkebunan sawit atau merupakan perusahaan yang bekerja untuk men-support pekerjaan di salah satu jenis perusahaan tersebut.

Sebanyak 38 perusahaan dari 439 perusahaan rental bersedia memberikan data pelanggannya. Data yang terkumpul menunjukkan bahwa setidaknya ada 1.023 perusahaan yang melakukan persewaan kendaraan dengan kriteria tersebut di atas. Jumlah perusahaan penyewa tersebut diambil sebagai populasi pada studi ini. Dari populasi, sejumlah sampel diambil untuk digunakan pada studi ini. Sampel diambil dari populasi dengan menggunakan teknik probability sampling dengan cara simple random sampling.

Ukuran atau jumlah sampel (data observasi) yang sesuai untuk teknik SEM menurut Hair et al. dalam Waluyo (2005: 1921) adalah antara 100-200 atau $5 \mathrm{X}$ n sampai 10 $\mathrm{X} \mathrm{n} \mathrm{(} \mathrm{n}=$ jumlah indikator). Jumlah indikator pada studi ini adalah 16, maka jumlah sampel minimal yang dibutuhkan ialah $10 \times 16=160$ sampel. Kuesioner yang disebar berjumlah 640 kuesioner atau empat kali jumlah sampel minimal.

\section{Variabel}

\section{Klasifikasi Variabel}

Variabel eksogen pada studi ini ialah reputasi perusahaan rental $\left(\mathrm{X}_{1}\right)$ dan relationship value $\left(\mathrm{X}_{2}\right)$. Ada dua variabel intervening, yakni komitmen perusahaan penyewa $\left(\mathrm{Y}_{2}\right)$ dan kepercayaan perusahaan penyewa $\left(\mathrm{Y}_{1}\right)$. Selain itu, terdapat satu variabel endogen, yaitu loyalitas perusahaan penyewa $\left(\mathrm{Y}_{3}\right)$.

\section{Definisi Operasional Variabel}

Definisi operasional merupakan suatu petunjuk pelaksanaan tentang interpretasi dan cara mengukur suatu variabel. Definisi operasional masing-masing variabel dipaparkan sebagai berikut:

\section{Reputasi Perusahaan Rental $\left(X_{1}\right)$}

Reputasi Perusahaan Rental $\left(\mathrm{X}_{1}\right)$ ialah evaluasi atau penilaian perusahaan penyewa mengenai kejujuran, keadilan dan kepedulian dari perusahaan rental (Wagner et al., 2011). Pengukuran terhadap variabel
Reputasi Perusahaan Rental $\left(\mathrm{X}_{1}\right)$ diadaptasi dari Wagner et al. (2011), yakni:

$\mathrm{X}_{1.1}$ Penilaian perusahaan penyewa terhadap kejujuran perusahaan rental dalam memaparkan kondisi kendaraan yang ditawarkannya.

$\mathrm{X}_{1.2}$ Penilaian perusahaan penyewa terhadap kesesuaian harga sewa yang diberikan perusahaan rental dengan kondisi kendaraannya.

$\mathrm{X}_{1.3}$ Penilaian perusahaan penyewa terhadap kecepatan perusahaan rental dalam merespon permintaan perbaikan kendaraan oleh perusahaan penyewa.

2. Relationship Value $\left(\mathrm{X}_{2}\right)$

Relationship Value $\left(\mathrm{X}_{2}\right)$ adalah nilai yang didapatkan oleh perusahaan penyewa terkait hubungannya dengan perusahaan rental (Eggert and Ulaga dalam Gil-Saura et al., 2009; Barry and Terry, 2008). Pengukuran terhadap variabel Relationship Value $\left(\mathrm{X}_{2}\right)$ diadaptasi dari Barry and Terry (2008), yakni:

$\mathrm{X}_{2.1}$ Harga sewa yang diberikan oleh perusahaan rental.

$\mathrm{X}_{2.2} \quad$ Kualitas kendaraan yang didapatkan dari perusahaan rental.

$\mathrm{X}_{2.3}$ Dukungan perusahaan rental terhadap sistem HSE (Health, Safety and Environment) yang dimiliki oleh perusahaan penyewa.

$\mathrm{X}_{2.4}$ Dukungan perusahaan rental pada aktivitas kerja perusahaan penyewa dengan menyediakan mekanik standby untuk mempercepat proses perbaikan kendaraan.

3. Kepercayaan Perusahaan Penyewa $\left(\mathbf{Y}_{1}\right)$ Kepercayaan Perusahaan Penyewa $\left(\mathrm{Y}_{1}\right)$ adalah rasa percaya perusahaan penyewa terhadap kehandalan, prioritas kepentingan dan pemenuhan janji dari perusahaan rental (Keh and Xie, 2009). Pengukuran terhadap variabel Kepercayaan Perusahaan Penyewa $\left(\mathrm{Y}_{1}\right)$ dilakukan menggunakan indikator yang diadaptasi dari Keh and Xie (2009), yakni:

$\mathrm{Y}_{1.1}$ Kepercayaan perusahaan penyewa terhadap kehandalan mekanik perusahaan rental dalam mengatasi kerusakan kendaraan dengan cepat.

$\mathrm{Y}_{1.2}$ Kepercayaan perusahaan penyewa bahwa perusahaan rental akan mendahulukan kewajibannya untuk 
memberikan jasa persewaan kendaraan yang baik dibandingkan menuntut pembayaran sewa atas kendaraan tersebut.

$\mathrm{Y}_{1.3}$ Kepercayaan perusahaan penyewa terhadap pemenuhan janji perusahaan rental dalam menyediakan kendaraan tepat waktu sesuai kontrak kerja yang disepakati.

4. Komitmen Perusahaan Penyewa $\left(\mathrm{Y}_{2}\right)$

Komitmen Perusahaan Penyewa $\left(\mathrm{Y}_{2}\right)$ adalah suatu keadaan keterikatan hubungan perusahaan penyewa dengan perusahaan rental yang terjadi karena perusahaan penyewa membutuhkan perusahaan rental dengan alasan yang rasional serta adanya motif ekonomi (Davis-Sramek et al., 2009). Pengukuran terhadap variabel Komitmen Perusahaan Penyewa $\left(\mathrm{Y}_{2}\right)$ diadaptasi dari Davis-Sramek et al. (2009), yakni:

$\mathrm{Y}_{2.1}$ Keterikatan perusahaan penyewa terhadap perusahaan rental yang membuat perusahaan penyewa menjaga hubungan dengan perusahaan rental untuk menghindari kesulitan yang dapat dialami perusahaan penyewa jika harus mengganti perusahaan rental yang ada saat ini dengan perusahaan rental lain.

$\mathrm{Y}_{2.2}$ Keterikatan perusahaan penyewa terhadap perusahaan rental yang membuat perusahaan penyewa tetap mempertahankan kontrak persewaan yang ada untuk menghindari kerugian finansial jika hubungannya dengan perusahaan rental berakhir.

$\mathrm{Y}_{2.3}$ Keterikatan perusahaan penyewa untuk tetap berhubungan dengan perusahaan rental untuk menghindari besarnya usaha (waktu dan energi) yang harus dikeluarkan perusahaan penyewa untuk mencari pengganti perusahaan rental.

\section{Loyalitas Perusahaan Penyewa $\left(\mathbf{Y}_{3}\right)$}

Loyalitas Perusahaan Penyewa $\left(\mathrm{Y}_{3}\right)$ adalah keadaan yang menunjukkan bahwa perusahaan penyewa memiliki perilaku untuk melakukan pembelian ulang, menginginkan untuk menggunakan perusahaan rental yang sama ketika membutuhkan jasa-jasa persewaan kendaraan dan menunjukkan perilaku yang positif terhadap perusahaan rental tersebut (Gremler and Brown dalam Gil-Saura et al., 2009). Pengukuran terhadap variabel Loyalitas Perusahaan Penyewa $\left(\mathrm{Y}_{3}\right)$ diadaptasi dari Tian et al. (2008), yakni:

$\mathrm{Y}_{3.1}$ Minat perusahaan penyewa untuk melakukan perpanjangan atau pembaharuan kontrak sewa dengan perusahaan rental bila masa kontraknya habis.

$\mathrm{Y}_{3.2}$ Keinginan perusahaan penyewa untuk melakukan permintaan terhadap jenis kendaraan lain dari perusahaan rental.

$\mathrm{Y}_{3.3}$ Pemberian rekomendasi oleh perusahaan penyewa kepada mitranya untuk menggunakan perusahaan rental yang sama dengan yang digunakannya.

\section{Instrumen Penelitian}

Instrumen utama yang digunakan dalam studi ini adalah kuesioner dengan pengukuran menggunakan skala Likert. Pengukuran dilakukan dengan cara meminta responden untuk menjawab persepsinya mewakili perusahaannya mengenai indikator-indikator yang digunakan pada setiap variabel. Responden menilai indikator menggunakan skala ordinal (skala likert) dengan lima pilihan jawaban, yaitu 1 : Sangat Tidak Setuju; 5 : Sangat Setuju (SS).

\section{Prosedur Pengambilan dan Teknik Pengumpulan Data}

Teknik pengambilan data pada studi ini ialah metode survei dengan teknik cross sectional menggunakan surat elektronik ( $e$ mail) dalam penyebaran kuesioner. Kuesioner yang disebarkan berisi daftar pertanyaan yang terdiri dari pertanyaan mengenai karakteristik responden dan pertanyaan tentang variabel yang diteliti. Pertanyaan disajikan dalam bentuk pernyataan dan skala untuk menyatakan respon.

\section{Model dan Teknik Analisis Data}

Studi ini menggunakan teknik analisis SEM (Structural Equation Modeling) yang digunakan untuk menganalisis hubungan kausal antar variabel pada model yang dibuat. Penggunaan SEM dilakukan melalui program 
komputer AMOS (Analysis of Moment Structure) versi 16. Alasan mendasar penggunaan analisis SEM adalah: Pertama, studi ini menggunakan variabel laten yang diukur melalui indikator (variabel observasi).
Kedua adalah SEM merupakan salah satu teknik analisis yang memungkinkan pengujian sebuah rangkaian hubungan yang relatif rumit secara simultan.

\section{HASIL ANALISIS}

Hasil Pengujian Validitas dan Reliabilitas

Hasil uji validitas dan reliabilitas tertera pada Tabel 5.7.

Tabel .1

HASIL UJI VALIDITAS DAN RELIABILITAS

\begin{tabular}{lccc}
\multicolumn{1}{c}{ Variabel } & GFI & $\begin{array}{c}\text { Construct } \\
\text { Reliability }\left(\boldsymbol{\rho}_{\boldsymbol{\pi}}\right)\end{array}$ & \multicolumn{1}{c}{ Keterangan } \\
\hline $\begin{array}{l}\text { Reputasi Perusahaan Rental } \\
\text { Relationship value }\end{array}$ & 1,000 & 0,755 & Valid unidimensional dan Reliabel \\
$\begin{array}{l}\text { Kepercayaan Perusahaan } \\
\begin{array}{l}\text { Penyewa } \\
\text { Komitmen Perusahaan }\end{array}\end{array}$ & 0,992 & 0,748 & Valid unidimensional dan Reliabel \\
$\begin{array}{l}\text { Penyewa } \\
\text { Loyalitas Perusahaan Penyewa }\end{array}$ & 1,000 & 0,752 & Valid unidimensional dan Reliabel \\
\hline
\end{tabular}

Hasil uji validitas menunjukkan masingmasing indikator variabel memiliki nilai $\mathrm{p}=$ 0,000 yang lebih kecil dari $\alpha=0,05$, maka dikatakan instrumen pengukuran yang digunakan sahih atau valid dan dapat digunakan untuk mengukur masing-masing variabel. Hasil uji validitas juga menunjukkan bahwa nilai GFI masing-masing variabel berada di atas nilai cutoff-nya sebesar 0,90 , maka dikatakan instrumen pengukuran valid unidimensional. Sedangkan hasil uji reliabilitas menunjukkan bahwa nilai construct reliability $\left(\rho_{\eta}\right)$ lebih besar dibanding nilai cut-off-nya sebesar 0,70 , maka dikatakan seluruh instrumen penelitian reliabel.

\section{Loading Factor}

Data yang ditampilkan pada Tabel 5.13 menunjukkan nilai loading factor dari variabel Reputasi Perusahaan Rental $\left(\mathrm{X}_{1}\right)$ yang terbesar terdapat pada indikator $\mathrm{X}_{1.3}(=0,760)$, yakni kecepatan merespon permintaan perbaikan. Sementara nilai loading factor dari variabel Relationship Value $\left(\mathrm{X}_{2}\right)$ yang terbesar terdapat pada indikator $\mathrm{X}_{2.1}(=0,720)$, yakni kemurahan harga sewa.

Data yang ditampilkan pada Tabel 5.13 menunjukkan pula nilai loading factor dari variabel Kepercayaan Perusahaan Penyewa $\left(\mathrm{Y}_{1}\right)$ yang terbesar terdapat pada indikator $\mathrm{Y}_{1.2}$ $(=0,711)$, yakni kepercayaan terhadap prioritas kepentingan perusahaan rental. Nilai loading factor dari variabel Komitmen Perusahaan Penyewa $\left(\mathrm{Y}_{2}\right)$ yang terbesar terdapat pada indikator $\mathrm{Y}_{2.2} \quad(=0,853)$, yakni komitmen perusahaan penyewa untuk mempertahankan kontrak. Sementara berdasarkan data yang ditampilkan, nilai loading factor dari variabel Loyalitas Perusahaan Penyewa $\left(\mathrm{Y}_{3}\right)$ yang terbesar terdapat pada indikator $\mathrm{Y}_{3.2}(=0,737)$, yakni permintaan terhadap jenis kendaraan lain.

Tabel .2

LOADING FACTOR INDIKATOR VARIABEL

\begin{tabular}{rrr}
\multicolumn{1}{c}{ Indikator } & $\begin{array}{r}\text { Loading } \\
\text { Factor }\end{array}$ \\
\hline Reputasi Perusahaan Rental $\left(\mathbf{X}_{\mathbf{1}}\right)$ & \\
$\mathrm{X}_{1.1}$ & Kejujuran terhadap kondisi kendaraan & 0,719 \\
$\mathrm{X}_{1.2}$ & Kesesuaian harga dengan kondisi kendaraan & 0,632 \\
$\mathrm{X}_{1.3}$ & Kecepatan merespon permintaan perbaikan & $\mathbf{0 , 7 6 0}$ \\
\hline & & 95 \\
\hline & & \\
Vol 5, No 2 (2016): Jurnal Ekonomika (Manajemen, Akuntansi, dan Perbankan Syari'ah)-EKONOMI-UWGM
\end{tabular}


Relationship Value $\left(\mathrm{X}_{2}\right)$

$\mathrm{X}_{2.1}$ Kemurahan harga sewa

$\mathrm{X}_{2.2}$ Kualitas kendaraan

0,673

$\mathrm{X}_{2.3}$ Dukungan terhadap sistem HSE

0,623

$\mathrm{X}_{2.4}$ Dukungan terhadap aktivitas kerja

0,648

Kepercayaan Perusahaan Penyewa $\left(Y_{1}\right)$

$\mathrm{Y}_{1.1}$ Kepercayaan terhadap kehandalan mekanik

0,657

$Y_{1.2}$ Kepercayaan terhadap prioritas kepentingan

$\mathbf{0 , 7 5 2}$

$\mathrm{Y}_{1.3}$ Kepercayaan terhadap pemenuhan janji

0,722

Komitmen Perusahaan Penyewa $\left(\mathbf{Y}_{2}\right)$

$\mathrm{Y}_{2.1}$ Keterikatan perusahaan penyewa untuk menjaga hubungan dengan perusahaan rental

$\mathrm{Y}_{2.2}$ Keterikatan perusahaan penyewa untuk mempertahankan kontrak dengan perusahaan rental

$\mathrm{Y}_{2.3}$ Keterikatan perusahaan penyewa untuk tetap berhubungan dengan perusahaan rental

Loyalitas Perusahaan Penyewa $\left(\mathbf{Y}_{3}\right)$

$\mathrm{Y}_{3.1}$ Minat untuk perpanjangan atau pembaharuan kontrak

$\mathrm{Y}_{3.2}$ Keinginan meminta jenis kendaraan lain

$\mathbf{0 , 7 9 2}$

$\mathrm{Y}_{3.3}$ Pemberian rekomendasi penggunaan jasa perusahaan rental

0,748

Uji Asumsi yang Melandasi SEM

Uji Normalitas Data

Tabel .3

HASIL EVALUASI NORMALITAS

Indikator

\section{Reputasi Perusahaan Rental $\left(\mathbf{X}_{1}\right)$}

$\mathrm{X}_{1.1}$ Kejujuran terhadap kondisi kendaraan

$-0,692$

$-0,177$

$-3,706$

$-0,948$

0,805

0,223

$\mathrm{X}_{1.2}$ Kesesuaian harga dengan kondisi kendaraan

Relationship Value $\left(\mathrm{X}_{2}\right)$

$\mathrm{X}_{2.1}$ Kemurahan harga sewa

$-0,004 \quad-0,021$

$-0,755$

$-1,113 \quad-5,960 \quad 1,973$

$\mathrm{X}_{2.2}$ Kualitas kendaraan

$-0,572 \quad-3,064$

0,140

5,281

$\mathrm{X}_{2.3}$ Dukungan terhadap sistem HSE

$-0,469 \quad-2,509$

$-0,602$

0,376

$\mathrm{X}_{2.4}$ Dukungan terhadap aktivitas kerja

Kepercayaan Perusahaan Penyewa $\left(\mathbf{Y}_{1}\right)$

$Y_{1.1}$ Kepercayaan terhadap kehandalan mekanik

$\mathrm{Y}_{1.2}$ Kepercayaan terhadap prioritas kepentingan

$-0,321 \quad-1,717$

$-0,416$

$-1,612$

$\mathrm{Y}_{1.3}$ Kepercayaan terhadap pemenuhan janji

$-0,296 \quad-1,586 \quad-0,441$

$-1,114$

$-0,483 \quad-2,586 \quad 0,322$

$-1,180$

0,863

Komitmen Perusahaan Penyewa $\left(\mathbf{Y}_{2}\right)$

$\mathrm{Y}_{2.1}$ Keterikatan perusahaan penyewa untuk menjaga hubungan dengan perusahaan rental

$$
0,321 \quad 1,721 \quad-0,894
$$

$\mathrm{Y}_{2.2}$ Keterikatan perusahaan penyewa untuk mempertahankan kontrak dengan perusahaan rental

$$
\begin{array}{llll}
0,645 & 3,451 & -0,547 & -1,465 \\
0,047 & 0,254 & -1,278 & -3,420
\end{array}
$$




\begin{tabular}{llrrrr}
\hline \multicolumn{1}{c|}{ Indikator } & skew & \multicolumn{1}{c|}{ c.r. } & \multicolumn{1}{c}{$\begin{array}{l}\text { Kur- } \\
\text { tosis }\end{array}$} & c.r. \\
\hline$Y_{3.1}$ & Minat untuk perpanjangan atau pembaharuan kontrak & 0,321 & 1,717 & $-0,838$ & $-2,244$ \\
Y $_{3.2}$ & Keinginan meminta jenis kendaraan lain & $-0,674$ & $-3,608$ & $-0,290$ & $-0,777$ \\
$Y_{3.3}$ & $\begin{array}{l}\text { Pemberian rekomendasi penggunaan jasa perusahaan } \\
\text { rental }\end{array}$ & $-0,219$ & $-1,170$ & 0,023 & 0,062 \\
& $\quad$ & & 16,656 & 4,551 \\
\hline
\end{tabular}

Tampak bahwa sebaran data pada 7 dari 16 indikator tidak terdistribusi normal secara univariate. Hasil pengujian normalitas data secara multivariate juga menunjukkan nilai c.r $=4,551$; sementara nilai $\mathrm{z}$ kritis adalah 2,58, dengan demikian c.r $>\mathrm{z}$ kritis. Hal ini menunjukkan bahwa secara multivariate data tidak berdistribusi normal.

Grinstead and Snell (1998: 359) mengatakan bahwa bilamana ukuran sampel semakin besar, berdasarkan pada Dalil Limit Pusat (Limit Central Theorm), maka statistik yang diperoleh akan mendekati distribusi normal. Atas dasar ini, sehingga asumsi normalitas dapat diabaikan atau dikatakan bahwa sampel dianggap terdistribusi normal berdasarkan Dalil Limit Pusat.

Namun, beberapa peneliti tidak berhenti pada teori tersebut dan melakukan beberapa tindakan agar data dapat terdistribusi normal, yakni mengurangi atau menambah data. Sebelum melakukan suatu tindakan tertentu atas adanya distribusi data yang tidak normal ini, Santoso (2011: 79) mengatakan perlu dilakukan terlebih dahulu evaluasi atas ada tidaknya data outliers.

\section{Uji Data Outliers}

Hasil pemeriksaan data menggunakan Jarak Mahalanobis menunjukkan terdapat 1 (satu) data pengamatan yang outliers, yakni

\section{Uji Kesesuaian Model}

Hasil pengujian sembilan hipotesis menggunakan model persamaan struktural dapat dilihat pada Gambar 1.3 pada observasi nomor 50. Kline (2011: 55) mengatakan bahwa data observasi yang outliers tidak dapat begitu saja dibuang atau tidak diikutsertakan pada analisis selanjutnya bila tidak ada alasan khusus. Oleh sebab itu, peneliti diminta untuk meninjau kembali data observasi yang outliers tersebut dan melihat profilnya. Bila terdapat perbedaan mencolok dengan data observasi lainnya, maka data dapat dihilangkan atau tidak diikutsertakan pada analisis selanjutnya. Hasil peninjauan pada observasi nomor 50 menunjukkan bahwa profilnya telah sesuai dengan karakteristik yang ditentukan pada studi ini. Atas dasar itu, data observasi nomor 50 tidak dihilangkan dari data studi ini atau tetap diikutsertakan pada analisis selanjutnya.

\section{Uji Linieritas}

Hasil pengujian linieritas menunjukkan bahwa semua hubungan antar variabel yang terdapat di dalam model struktural adalah linier. Hal tersebut dapat diketahui dari hasil pengujian linieritas di Lampiran 6 pada sembilan hubungan antar variabel yang menunjukkan Sig $F=0.000$. Nilai tersebut kurang dari 0,05 yang merupakan tingkat signifikansi yang ditentukan, sehingga dikatakan bahwa asumsi linieritas terpenuhi.

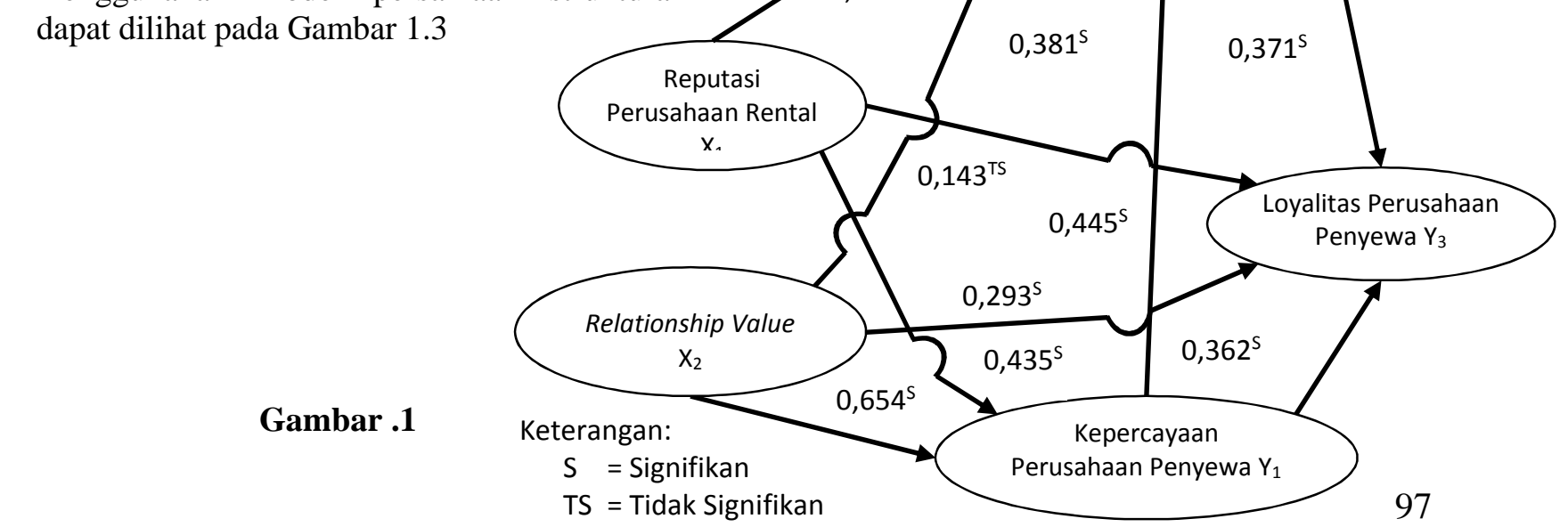

Vol 5, No 2 (2016): Jurnal Ekonomika (Manajemen, Akuntansi, dan Perbankan Syari'ah)-EKONOMI-UWGM 


\section{MODEL PERSAMAAN STRUKTURAL} (HASIL UJI HIPOTESIS)

Fit atau tidaknya model persamaan struktural pada Gambar 5.1 perlu dievaluasi. Hasil evaluasi model persamaan struktural disajikan pada Tabel

Data pada Tabel 1.4 menunjukkan ada empat kriteria goodness of fit yang telah terpenuhi. Hal tersebut sudah menunjukkan bahwa model fit atau memenuhi kriteria model persamaan struktural yang baik. Empat kriteria goodness of fit yang telah terpenuhi yang dimaksud di atas ialah RMSEA, CMIN/DF, TLI dan CFI. Sementara nilai Chi Square tidak memenuhi syarat. Nilai GFI dan AGFI dikatakan marginal karena mendekati nilai cutoff yang dipersyaratkan, artinya masih dapat diterima. Nilai cut-off pada kriteria-kriteria tersebut didasarkan pada panduan Ghozali (2008: 67-68) dan Santoso (2011: 102-107).

Tabel .4

HASIL PENGUJIAN MODEL PERSAMAAN STRUKTURAL

\begin{tabular}{lccc}
\multicolumn{1}{c}{ Kriteria } & Hasil Perhitungan & Cut-off & Keterangan \\
\hline Chi Square & 187,343 & Kecil & $\chi^{2}$ tabel df = 95 ialah 118,752 \\
Probabilitas & 0,000 & $>0,050$ & Ho ditolak \\
CMIN/DF & 1,972 & $\leq 2,000$ & Model Baik \\
RMSEA & 0,075 & $\leq 0,080$ & Model Baik \\
GFI & 0,891 & $\geq 0,900$ & Marginal \\
AGFI & 0,843 & $\geq 0,900$ & Marginal \\
TLI & 0,906 & $\geq 0,900$ & Model Baik \\
CFI & 0,926 & $\geq 0,900$ & Model Baik \\
\hline
\end{tabular}

\subsection{Hasil Pengujian Hipotesis}

Hasil pengujian hipotesis tersebut dapat dilihat pada Tabel 1.5

\section{Tabel .5}

HASIL UJI HIPOTESIS

\begin{tabular}{|c|c|c|c|c|c|}
\hline Hipotesis & $\begin{array}{l}\text { Variabel yang } \\
\text { Mempengaruhi }\end{array}$ & $\begin{array}{l}\text { Variabel yang } \\
\text { Dipengaruhi }\end{array}$ & Koef. & C.R. & Keterangan \\
\hline 1 & $\begin{array}{l}\text { Reputasi Perusahaan } \\
\text { Rental }\left(\mathrm{X}_{1}\right)\end{array}$ & $\begin{array}{l}\text { Kepercayaan Perusahaan } \\
\text { Penyewa }\left(\mathrm{Y}_{1}\right)\end{array}$ & 0,435 & 4,286 & Signifikan \\
\hline 2 & $\begin{array}{l}\text { Reputasi Perusahaan } \\
\text { Rental }\left(\mathrm{X}_{1}\right)\end{array}$ & $\begin{array}{l}\text { Komitmen Perusahaan } \\
\text { Penyewa }\left(\mathrm{Y}_{2}\right)\end{array}$ & 0,230 & 2,175 & Signifikan \\
\hline 3 & $\begin{array}{l}\text { Reputasi Perusahaan } \\
\text { Rental }\left(\mathrm{X}_{1}\right)\end{array}$ & $\begin{array}{l}\text { Loyalitas Perusahaan } \\
\text { Penyewa }\left(\mathrm{Y}_{3}\right)\end{array}$ & 0,143 & 1,358 & $\begin{array}{c}\text { Tidak } \\
\text { Signifikan }\end{array}$ \\
\hline 4 & $\begin{array}{l}\text { Relationship Value } \\
\left(\mathrm{X}_{2}\right)\end{array}$ & $\begin{array}{l}\text { Loyalitas Perusahaan } \\
\text { Penyewa }\left(\mathrm{Y}_{3}\right)\end{array}$ & 0,293 & 2,015 & Signifikan \\
\hline 5 & $\begin{array}{l}\text { Relationship Value } \\
\left(\mathrm{X}_{2}\right)\end{array}$ & $\begin{array}{l}\text { Kepercayaan Perusahaan } \\
\text { Penyewa }\left(\mathrm{Y}_{1}\right)\end{array}$ & 0,654 & 5,547 & Signifikan \\
\hline 6 & $\begin{array}{l}\text { Relationship Value } \\
\left(\mathrm{X}_{2}\right)\end{array}$ & $\begin{array}{l}\text { Komitmen Perusahaan } \\
\text { Penyewa }\left(\mathrm{Y}_{2}\right)\end{array}$ & 0,381 & 2,721 & Signifikan \\
\hline 7 & $\begin{array}{l}\text { Kepercayaan } \\
\text { Prusahan Penyewa } \\
\left(\mathrm{Y}_{1}\right)\end{array}$ & $\begin{array}{l}\text { Komitmen Perusahaan } \\
\text { Penyewa }\left(\mathrm{Y}_{2}\right)\end{array}$ & 0,445 & 2,686 & Signifikan \\
\hline
\end{tabular}




\begin{tabular}{cllccc}
\hline 8 & $\begin{array}{l}\text { Kepercayaan } \\
\text { Prusahan Penyewa } \\
\left(\mathrm{Y}_{1}\right)\end{array}$ & $\begin{array}{l}\text { Loyalitas Perusahaan } \\
\text { Penyewa }\left(\mathrm{Y}_{3}\right)\end{array}$ & 0,362 & 2,047 & Signifikan \\
9 & $\begin{array}{l}\text { Komitmen Perusahaan } \\
\text { Penyewa }\left(\mathrm{Y}_{2}\right)\end{array}$ & $\begin{array}{l}\text { Loyalitas Perusahaan } \\
\text { Penyewa }\left(\mathrm{Y}_{3}\right)\end{array}$ & 0,371 & 2,327 & Signifikan \\
\hline
\end{tabular}

\section{Temuan Teoritis}

1. Studi ini menambah literatur pada relationship marketing dan $B 2 B$ marketing yang sebelumnya dipaparkan oleh Hutt and Speh (2010), yakni loyalitas sebagai tujuan dari relationship marketing dapat dicapai melalui kepercayaan dan komitmen pelanggan kepada provider. Pengembangan terhadap teori tersebut dilakukan melalui temuan hasil studi yang menunjukkan bahwa reputasi provider juga mempengaruhi loyalitas walaupun pengaruh tersebut secara tidak langsung melalui kepercayaan dan komitmen, sementara reputasi provider dapat mempengaruhi kepercayaan dan komitmen tersebut secara langsung. Selain itu, hasil studi juga menunjukkan bahwa relationship value berpengaruh secara langsung maupun tidak langsung terhadap loyalitas pelanggan melalui kepercayaan dan komitmen, sekaligus relationship value juga mempengaruhi kepercayaan dan komitmen tersebut.

2. Studi ini juga menambah literatur yang ada pada $B 2 B$ relationship service marketing melalui indikator yang digunakan untuk mengukur variabel relationship value. Pertama, penggunaan indikator ini mengembalikan sekaligus menguatkan penerapan pengukuran relationship value yang dicetuskan oleh Wilson and Jantrania (1994). Kedua, relationship value sebelumnya banyak digunakan pada studi dalam ranah goods marketing, sementara studi ini berada pada service marketing. Hasil uji validitas dan reliabilitas membuktikan bahwa seluruh indikator dapat mengukur dengan baik variabel relationship value. Hal ini memperkuat studi terdahulu tersebut mengenai penerapan pengukuran relationship value baik dalam goods marketing maupun service marketing sekaligus menambah cara-cara penerapan pengukuran variabel tersebut.

\section{Temuan Empirik}

1. Studi ini memberikan kontribusi terhadap adanya hasil uji pengaruh antar variabel. Hubungan antar variabel yang dimaksud ialah hubungan variabel reputasi terhadap kepercayaan, reputasi terhadap komitmen, reputasi terhadap loyalitas, relationship value terhadap loyalitas, relationship value terhadap kepercayaan, relationship value terhadap komitmen, kepercayaan terhadap komitmen, kepercayaan terhadap loyalitas, dan komitmen terhadap loyalitas. Kesembilan hubungan antar variabel yang telah diuji memperkokoh beberapa temuan dan melemahkan beberapa lainnya dari hasil studi terdahulu.

2. Ditemukan bahwa reputasi perusahaan rental berpengaruh tidak signifikan terhadap loyalitas perusahaan penyewa secara langsung. Hal tersebut dapat terjadi sebab reputasi perusahaan rental hanya berguna di awal hubungan persewaan kendaraan bagi perusahaan penyewa. Reputasi perusahaan rental menjadi dasar bagi perusahaan penyewa untuk dapat menerimanya dalam suatu hubungan. Artinya, bila penilaian perusahaan penyewa terhadap perusahaan rental menunjukkan perusahaan rental merupakan perusahaan yang baik, maka perusahaan penyewa bersedia menerima perusahaan rental menjadi penyedia kendaraan baginya. Setelah hubungan terjadi, penyewaan ulang, pengembangan kerja sama berupa penyediaan jenis kendaraan lain dan rekomendasi terhadap penggunaan perusahaan rental kepada pihak lain atau loyalitas perusahaan penyewa terhadap perusahaan rental ditentukan oleh relationship value, kepercayaan dan komitmen perusahaan penyewa terhadap perusahaan rental.

3. Hubungan antar variabel dengan nilai koefisien terbesar $(0,654)$ berada pada pengaruh relationship value terhadap kepercayaan perusahaan penyewa. Artinya kepercayaan perusahaan penyewa terhadap 
perusahaan rental dipengaruhi lebih kuat oleh nilai yang didapatkan perusahaan penyewa ketika berhubungan dengan perusahaan rental dibandingkan dengan nilai reputasi yang dimiliki oleh perusahaan rental.

4. Nilai loading factor terbesar berada pada indikator komitmen perusahaan rental, yakni keterikatan perusahaan penyewa untuk mempertahankan kontrak dengan perusahaan rental. Hal ini menunjukkan bahwa komitmen perusahaan penyewa kepada perusahaan rental dibentuk lebih besar oleh keterikatan perusahaan penyewa untuk mempertahankan kontrak dengan perusahaan rental. Namun, nilai rata-rata

\section{PENUTUP}

Kesimpulan dari studi ini ialah sebagai berikut:

1. Reputasi perusahaan rental berpengaruh signifikan terhadap kepercayaan perusahaan penyewa pada jasa persewaan kendaraan di Kalimantan Timur. Hasil studi ini menunjukkan bahwa naiknya reputasi perusahaan rental akan meningkatkan kepercayaan perusahaan penyewa pada perusahaan rental, demikian sebaliknya. Reputasi yang baik dari suatu perusahaan rental akan membuat perusahaan penyewa percaya dalam berhubungan dengan perusahaan rental tersebut. Reputasi sebagai nama baik perusahaan rental memberikan keyakinan kepada perusahaan penyewa mengenai kejujuran dan performa perusahaan rental. Perusahaan penyewa lebih mudah percaya dan tetap terjaga kepercayaannya kepada perusahaan rental yang dinilai profesional dan berkemampuan dalam bidangnya.

2. Reputasi perusahaan rental berpengaruh signifikan terhadap komitmen perusahaan penyewa pada jasa persewaan kendaraan di Kalimantan Timur. Hasil studi ini menunjukkan bahwa naiknya reputasi perusahaan rental akan meningkatkan komitmen perusahaan penyewa pada perusahaan rental, demikian sebaliknya. Perusahaan penyewa menjadi lebih berkomitmen dalam hubungan persewaan kendaraan yang terjalin dengan adanya reputasi perusahaan rental yang baik. Perusahaan penyewa merasa nyaman indikator tersebut berada di posisi terendah dari indikator lainnya pada variabel komitmen yang berarti perusahaan penyewa masih kurang peduli dengan hal ini.

Data yang diperoleh menunjukkan perusahaan yang bergerak pada bidang usaha batu bara merupakan pengguna utama jasa persewaan kendaraan di Kalimantan Timur. Kutai Kartanegara adalah kabupaten yang memiliki jumlah perusahaan penyewa terbesar. Masa sewa yang paling sering digunakan ialah dua tahun.

dalam berhubungan dan merasa ingin berhubungan lebih jauh dengan perusahaan rental yang mampu mempertahankan dan meningkatkan reputasinya.

3. Reputasi perusahaan rental berpengaruh tidak signifikan terhadap loyalitas perusahaan penyewa secara langsung pada jasa persewaan kendaraan di Kalimantan Timur. Hasil studi ini menunjukkan bahwa pengaruh positif dari reputasi perusahaan rental terhadap loyalitas perusahaan penyewa secara langsung tidak nyata. Perusahaan penyewa tidak serta merta menjadi loyal atas tingginya reputasi perusahaan rental di mata perusahaan penyewa. Atau dengan kata lain, reputasi perusahaan rental bukan hal yang penting lagi bagi keberlanjutan hubungan menurut perusahaan penyewa.

4. Relationship value berpengaruh signifikan terhadap loyalitas perusahaan penyewa pada jasa persewaan kendaraan di Kalimantan Timur. Hasil studi ini menunjukkan bahwa naiknya relationship value akan meningkatkan loyalitas perusahaan penyewa pada perusahaan rental, demikian sebaliknya. Loyalitas perusahaan penyewa menjadi lebih tinggi bila perusahaan rental mampu memberikan relationship value yang tinggi baginya. Perusahaan penyewa ingin terus melakukan hubungan persewaan kendaraan disebabkan value yang didapatkan dari perusahaan rental.

5. Relationship value berpengaruh signifikan terhadap kepercayaan perusahaan penyewa 
pada jasa persewaan kendaraan di Kalimantan Timur. Hasil studi ini menunjukkan bahwa naiknya relationship value akan meningkatkan kepercayaan perusahaan penyewa pada perusahaan rental, demikian sebaliknya. Perusahaan penyewa akan percaya terhadap kemampuan perusahaan rental bila perusahaan rental dapat memberikan relationship value yang tinggi bagi perusahaan penyewa. Value yang tinggi yang didapatkan perusahaan penyewa dari perusahaan rental membuat perusahaan penyewa yakin terhadap kemampuan perusahaan rental.

6. Relationship value berpengaruh signifikan terhadap komitmen perusahaan penyewa pada jasa persewaan kendaraan di Kalimantan Timur. Hasil studi ini menunjukkan bahwa naiknya relationship value akan meningkatkan komitmen perusahaan penyewa pada perusahaan rental, demikian sebaliknya. Keinginan perusahaan penyewa untuk berkomitmen terhadap hubungannya dengan perusahaan rental semakin tinggi bila perusahaan rental dapat memberikan relationship value yang tinggi. Adanya value yang tinggi yang berasal dari menyewa kendaraan kepada perusahaan rental membuat perusahaan penyewa merasa terikat dan rugi bila hubungan persewaan tersebut berakhir.

7. Kepercayaan perusahaan penyewa berpengaruh signifikan terhadap komitmen perusahaan penyewa pada jasa persewaan kendaraan di Kalimantan Timur. Hasil studi ini menunjukkan bahwa naiknya kepercayaan perusahaan penyewa akan meningkatkan komitmen perusahaan penyewa pada perusahaan rental, demikian sebaliknya. Semakin tinggi kepercayaan perusahaan penyewa kepada perusahaan rental maka akan semakin tinggi pula komitmennya terhadap hubungan kerja mereka. Perusahaan penyewa bersedia untuk berhubungan dengan lebih mendalam kepada perusahaan rental yang dipercaya tidak akan melakukan perbuatan yang merugikannya.

8. Kepercayaan perusahaan penyewa berpengaruh signifikan terhadap loyalitas perusahaan penyewa pada jasa persewaan kendaraan di Kalimantan Timur. Hasil studi ini menunjukkan bahwa naiknya kepercayaan perusahaan penyewa akan meningkatkan loyalitas perusahaan penyewa pada perusahaan rental, demikian sebaliknya. Perusahaan penyewa akan loyal kepada perusahaan rental bila perusahaan penyewa telah merasa percaya terhadap kemampuan perusahaan rental. Perusahaan penyewa ingin berhubungan secara berkesinambungan dengan perusahaan rental yang diyakininya tidak mengambil kesempatan yang akan merugikannya.

9. Komitmen perusahaan penyewa berpengaruh signifikan terhadap loyalitas perusahaan penyewa pada jasa persewaan kendaraan di Kalimantan Timur. Hasil studi ini menunjukkan bahwa naiknya komitmen perusahaan penyewa akan meningkatkan loyalitas perusahaan penyewa pada perusahaan rental, demikian sebaliknya. Keinginan perusahaan penyewa untuk berhubungan secara jangka panjang menjadi tinggi bila perusahaan penyewa merasa lebih terikat dengan perusahaan rental. Keterikatan tersebut didasarkan pada kekhawatiran terhadap adanya dampak kerugian bilamana memutuskan hubungan dengan perusahaan rental.

10. Hasil studi ini secara teoritik menambah literatur dalam relationship B2B marketing melalui pengujian pengaruh relationship value dan reputasi provider terhadap kepercayaan, komitmen dan loyalitas pelanggan.

11. Nilai koefisien tertinggi ditemukan pada pengaruh relationship value terhadap kepercayaan perusahaan penyewa. Artinya perusahaan penyewa tidak akan percaya kepada perusahaan rental yang tidak mampu memberikan yang terbaik bagi perusahaan penyewa. Harga sewa kendaraan yang murah bagi perusahaan penyewa menunjukkan perusahaan rental mengutamakan kepentingannya. Hal ini didukung dengan nilai loading factor dari indikator kemurahan harga sewa yang memberikan sumbangan terbesar untuk relationship value dan indikator kepercayaan terhadap prioritas kepentingan.

12. Loyalitas sebagai tujuan akhir yang ingin dicapai oleh perusahaan rental sangat dipengaruhi oleh komitmen yang 
ditunjukkan dengan nilai koefisien terbesar berada pada hubungan antar variabel ini. Namun begitu, kepercayaan perusahaan penyewa mempengaruhi loyalitas dengan nilai koefisien yang berbeda tipis. Oleh sebab itu, loyalitas perusahaan penyewa dikatakan meningkat dan menurun bergantung dari komitmen dan kepercayaannya kepada perusahaan rental. Kepercayaan di sisi lain dipengaruhi dengan nilai koefisien terbesar oleh relationship value, sementara nilai koefisien relationship value - komitmen hanya separuhnya. Dengan kata lain, pencapaian loyalitas perusahaan penyewa yang tinggi dapat diwujudkan bila perusahaan rental memperhatikan

\section{DAFTAR PUSTAKA}

Abolhasapour M, Esfahani MMS, Kimiagari MA, Abolhasanpoor $\mathrm{A}$, and Tajalli $\mathrm{M}$, 2011. Power, Cooperation, Trust and Commitment in Supplier-Buyer Relationships. Journal of American Science, Vol. 7, No. 8, pp. 820-826.

Anderson E and Weitz B, 1992. The Use of Pledges to Build and Sustain Commitment in Distribution Channels. Journal of Marketing Research, Vol. 29, No. 1, pp. 18-34.

ASPANJI, 2011. Laporan Tahunan 2011. Kalimantan Timur: Asosiasi Pengusaha Pengadaan Barang dan Jasa Indonesia.

Bansal HS, Irving PG and Taylor SF, 2004. A Three-Component Model of Customer Commitment to Service Providers. Journal of the Academy of Marketing Science, Vol. 32, No. 3, pp. 234-250.

Baron S, Conway T and Warnaby G, 2010. Relationship Marketing: A Consumer Experience Approach. Cornwall, England: SAGE Publication, Inc.

Barry J and Terry TS, 2008. Empirical Study of Relationship Value in Industrial Services. Journal of Business \& Industrial Marketing, Vol. 23, No. 4, pp. 228-241.

Bennet R and Gabriel H, 2001. Reputation, Trust and Supplier Commitment The Case of Shipping Company/ Seaport Relations. Journal of Business and Industrial Marketing, Vol. 16, No. 6, pp. 424-438. kepercayaan perusahaan penyewa terhadapnya dengan terlebih dahulu memberikan relationship value yang tinggi. Sementara itu, berdasarkan kesimpulan dari pembuktian kesembilan hipotesis, maka dapat disusun kesimpulan secara umum bahwa reputasi perusahaan rental dan relationship value berpengaruh secara langsung atau tidak langsung terhadap loyalitas perusahaan penyewa melalui kepercayaan dan komitmen perusahaan penyewa kepada perusahaan rental, kecuali pada hubungan reputasi perusahaan rental yang ditemukan berpengaruh tidak signifikan terhadap loyalitas perusahaan penyewa secara langsung.

Brennan R, Canning LE and McDowell R, 2010. Business-to-Business Marketing. Second Edition, London, England: SAGE Publication, Inc.

Brink A and Berndt A, 2008. Relationship Marketing and Customer Relationship Management. Lansdowne, South Africa: Juta and Company Ltd.

Caceres RC and Paparoidamis NG, 2007. Service Quality, Relationship Satisfaction, Trust, Commitment and Business-toBusiness Loyalty. European Journal of Marketing, Vol. 41, No. 7, Issue 8, pp. 836-867.

Cahill DL, 2007. Customer Loyalty in Third Party Logistics Relationships: Findings from Studies in Germany and The USA. Heidelberg, Germany: Springer.

Čater B and Čater T, 2009. Relationship-ValueBased Antecedents of Customer Satisfaction and Loyalty in Manufacturing. Journal of Business \& Industrial Marketing, Vol. 24, Issue 8, pp. 585-597.

Cheng Z, 2009. Value-Based Management of Supplier. Lohmar, Jerman: Josef Eulf Verlag GmbH.

Cretu AE and Brodie RJ, 2007. The Influence of Brand Image and Company Reputation where Manufacturers Market to Small Firms: A Customer Value Perspective. Industrial Marketing Management, Vol. 36, pp. 230-240.

Davis-Sramek B, Droge C, Mentzer JT, and Myers MB, 2009. Creating Commitment and Loyalty Behavior Among Retailers: 
What are The Roles of Service Quality and Satisfaction? Journal of the Academy Marketing Science, Vol. 37, No. 4, pp. 440-464.

Deligonul S, Kim D, Roath AS, and Cavusgil E, 2006. The Achilles' Heel of an Enduring Relationship: Appropriation of Rents between a Manufacturer and its Foreign Distributor. Journal of Business Research, Vol. 59, pp. 802-810.

Doney PM, Barry JM and Abratt R, 2007. Trust Determinants and Outcomes in Global B2B Services. European Journal of Marketing, Vol. 41, No. 9, Issue 10, pp. 1096-1116.

Doney PM and Cannon JP, 1997. An Examination of the Nature of Trust in Buyer-Seller Relationships. Journal of Marketing, Vol. 61, pp. 35-51.

Dwyer FR, Schürr PH and Oh S, 1987. Developing Buyer-Seller Relationship. Journal of Marketing, Vol. 51, April, pp. 11-27.

Falkenreck C, 2010. Reputation Transfer to Enter New B-to-B Markets: Measuring and Modelling Approaches. Heidelberg, Germany: Springer.

Fink and Reiners T, 2006. Modeling and Solving the Short-Term Car Rental Logistics Problem. Transportation Research, Part E 42, pp. 272-292.

Ganesan S, 1994. Determinants of Long-Term Orientation in Buyer-Seller Relationships. Journal of Marketing, Vol. 58, pp. 1-19.

Ghozali I, 2008. Model Persamaan Struktural: Konsep dan Aplikasi dengan Program AMOS 16.0. Semarang: Badan Penerbit Universitas Diponegoro.

Gil-Saura I, Frasquet-Deltoro $\mathrm{M}$ and CerveraTaulet A, 2009. The value of B2B Relationships. Industrial Management \& Data Systems, Vol. 109 No. 5, pp. 593609.

Grinstead CM and Snell JL, 1998. Introduction toProbability. Second Revised Edition, Rhode Island, USA: American Mathematical Society.

Ha HY, Janda S and Muthaly SK, 2010. A New Understanding of Satisfaction Model in ERe-Purchase Situation. European Journal of Marketing, Vol. 44, No. 7, issue 8, pp. 997-1016.

Hoffman KD and Bateson JEG, 2010. Services Marketing: Concepts, Strategies, and
Cases. Fourth Edition, Ohio, USA: Cengage Learning

Hutt MD and Speh TW, 2010. Business marketing management: B2B. Tenth Edition, Ohio, USA: Cengage Learning.

Jones MA, Reynolds KE, Mothersbaugh DL, and Beatty SE, 2007. The Positive and Negative Effects of Switching Costs on Relational Outcomes. Journal of Service Research, Vol. 9, No. 4, pp. 335-355.

Kamaluddin R, 2003. Ekonomi Transportasi: Karakteristik, Teori dan Kebijakan. Jakarta: Ghalia Indonesia.

Keh HT and Xie Y, 2009. Corporate Reputation and Customer Behavioral Intentions: The Roles of Trust, Identification and Commitment. Industrial Marketing Management, Vol. 38, pp. 732-742.

Kline RB, 2011. Principles and Practice of Structural Equation Modelling. Third Edition, New York, USA: The Guilford Press.

Kotler $\mathrm{P}$ and Keller KL, 2006. Marketing Management. 12e Edition, New Jersey, USA: Pearson Prentice Hall.

Lenox M, 2002. Organizational Design, Information Transfer, and The Acquisition Of Rent-Producing Resources. Computational and Mathematical Organization Theory, Vol. 8, pp. 113-131.

Lovelock CH and Wright LK, 1999. Principles of Service Marketing and Management. New Jersey, USA: Prentice Hall, Inc.

Mathur UC, 2008. Business to Business Marketing. New Delhi: New Age International.

McDonald M, Frow P and Payne A, 2011. Marketing Plans for Services: A Complete Guide. Third Edition, West Sussex, England: John Wiley and Sons, Inc.

Milewicz J and Herbig P, 1994. Evaluating The Brand Extension Decision Using A Model Of Reputation Building. The Journal of Product and Brand Management, Vol. 3, Ed 1, pp. 39-48.

Miremadi A, Babakhani N, Yousefian M, and Fotoohi H, 2011. Importance of the Corporate Reputation in B2B Context in Iran: An Empirical Study. International Journal of Marketing Studies, Vol. 3, No. 4, pp. 146-157.

Molinari LK, Abratt R and Dion P, 2008. Satisfaction, Quality and Value and Effects on Repurchase and Positive Word- 
of-Mouth Behavioral Intentions in A B2B Services Context. Journal of Services Marketing, Vol. 22, No. 5, pp. 363-373.

Moliner MA, Sanchez J, Rodriguez RM and Callarisa L, 2007. Perceived Relationship Quality and Post-Purchase Perceived Value. European Journal of Marketing, Vol. 41, No. 11, Issue 12, pp. 1392-1422.

Morgan RM and Hunt SD, 1994. The Commitment-Trust Theory of Relationship Marketing. Journal of Marketing, Vol. 58, pp. 20-38.

Morgan F, Schmelz DD and Moberg CR, 2007. Branding Implications of Partner FirmFocal Firm Relationships in Business-ToBusiness Service Networks. Journal of Business dan Industrial Marketing, Vol. 22, No. 6, pp. 372-382.

Morris MH, Pitt LF and Honeycutt ED, 2001. Business-To-Business Marketing: A Strategic Approach. Third Edition, California, USA: SAGE Publication, Inc.

Nasution MN, 2004. Manajemen Transportasi. Ed 2, Jakarta: Ghalia Indonesia.

Pick D, 2010. Never Say Never: Status Quo and Research Agenda for Relationship Termination in B2B Markets. Journal of Business Marketing Management. Vol. 4, pp. 91-108.

Rauyruen P and Miller KE, 2007. Relationship Quality as a Predictor of B2B Customer Loyalty. Journal of Business Research, 60 , pp. 21-31.

Ravald A and Grönroos C, 1996. The Value Concept and Relationship Marketing. European Journal of Marketing, Vol. 30 No. 2, pp. 19-30.

Salim HAA, 2006. Manajemen Transportasi. Ed 1, Jakarta: PT. Raja Grafindo Persada.

Santoso S, 2011. Structural Equation Modelling: Konsep dan Aplikasi dengan AMOS 18. Jakarta: PT. Elex Media Komputindo.

Sharif KJ, Kalafatis SP and Samouel P, 2005. Cognitive and Behavioural Determinants of Trust in Small and Medium-Sized Enterprises. Journal of Small Business and Enterprise Development, Vol. 12, No. 3, pp. 409-421.

Suh T and Houston MB, 2010. Distinguishing Supplier Reputation from Trust in BuyerSupplier Relationships. Industrial Marketing Management, Vol. 39, pp. 744751.
Tian Y, Lai F and Daniel F, 2008. An Examination of The Nature of Trust in Logistics Outsourcing Relationship: Empirical Evidence from China. Industrial Management \& Data Systems, Vol. 108, No. 3, pp. 346-367.

Ulaga W and Eggert A, 2006. Relationship Value and Relationship Quality: Broadening The Nomological Network of Business-to-Business Relationships. European Journal of Marketing, Vol. 40, no. 3, Issue 4, pp. 311-327.

Verma HV, 2007. Services Marketing: Text and Cases. Delhi, India: Pearson Education.

Wagner SM, Coley LS and Lindemann E, 2011. Effects of Suppliers' Reputation on The Future of Buyer-Supplier Relationship: The Mediating Roles of Outcome Fairness and Trust. Journal of Supply Chain Management, Vol. 47, No. 2, pp. 29-48.

Waheed KA, Jaleel $\mathrm{M}$ and Laeequddin $\mathrm{M}$, 2011. Prescription Loyalty Behavior of Physicians: An Empirical Study in India. International Journal of Pharmaceutical and Heathcare Marketing, Vol. 5 No. 4, pp 279-298.

Walter A, Mueller TA, Helfert G, Wilson DT, 2002. Delivering Relationship Value: Key Determinant for Customers' Commitment. ISBM Report, Vol. 8, The Pennsylvania State University, pp. 1-29.

Walsh G and Beatty SE, 2007. Customer-Based Corporate Reputation of A Service Firm: Scale Development and Validation. Journal of the Academic Marketing Science, Vol. 35, pp. 127-143.

Waluyo M, 2005. Panduan dan Aplikasi Structural Equation Modeling: untuk Aplikasi Model dalam Penelitian Teknik Industri dan Manajemen. Jilid 1, Surabaya: Yayasan Humaniora.

Wilson DT and Jantrania S, 1994. Understanding The Value of A Relationship. Asia Australia Marketing Journal, Vol. 2, No. 1, pp. 55-66.

Yanamandram V and White L, 2010. An Empirical Analysis of The Retention of Dissatisfied Business Services Custumers Using Structural Equation Modelling. Australasian Marketing Journal, Vol. 18, pp. 222-232. 